\title{
Analysis of Hard Water Coagulation in Water Sources of Kawatuna using Aloe Vera Plant
}

\author{
*Baby Melyta Pallar, Paulus Hengky Abram \& Purnama Ningsih \\ Pendidikan Kimia/FKIP - Universitas Tadulako, Palu - Indonesia 94119 \\ Received 24 March 2020, Revised 28 April 2020, Accepted 31 May 2020 \\ doi: $10.22487 / j 24775185.2020 . v 9 . i 2 . p p 125-132$
}

\begin{abstract}
Aloe vera gel is one of the plants that can be used as a natural coagulant. The chemical content in aloe vera has similarities to the cactus with the presence of mucilago or gel which can be used to purify water. This study aimed to determine the ability of aloe vera gel as a natural coagulant for water purification of Kawatuna water source and to determine the optimum volume of aloe vera gel. The steps of the study were preparing water sample, preparing aloe vera gel, coagulating of water, and analyzing parameters of water qualities i.e hardness, turbidity, color, temperature, $p H$, and total dissolved solid (TDS). The results showed that aloe vera gel was able to be used as a natural coagulant to purify water with the optimum ratio of $1 \mathrm{~mL}$ of aloe vera gel in $500 \mathrm{~mL}$ of water sample. Aloe vera gel reduced turbidity, hardness and color by 58.33, 15.45, and 50.36\%, respectively, with the pH of 4.1, temperatures at $30^{\circ} \mathrm{C}$ and TDS of $77.51 \%$. This study concluded that aloe vera gel able to be used as a coagulant to purify water.
\end{abstract}

Keywords: Aloe vera, natural coagulant, purification, water source

\section{Pendahuluan}

Air merupakan kebutuhan pokok yang tidak dapat dipisahkan dalam kehidupan mahkluk hidup. Air dimanfaatkan manusia untuk berbagai kebutuhan hidup seperti kebutuhan untuk rumah tangga, industri, pertanian, rekreasi, dan kebutuhan lainnya. Kebutuhan air untuk keperluan sehari-hari berbeda untuk tiap tempat dan tiap tingkatan kebutuhan. Semakin tinggi taraf kehidupan, maka semakin meningkat pula sejumlah kebutuhan akan air. Pemakaian air sangat luas, sehingga harus diupayakan sedemikian rupa agar tetap tersedia dan memenuhi persyaratan-persyaratan tertentu baik fisik, biologi maupun kimia (Alwi dkk., 2012).

Air bersih sangat dibutuhkan dalam kehidupan sehari-hari. Air yang kita ambil dari sumber air biasanya masih terdapat kotoran sehingga air tampak keruh dan tidak bisa langsung kita manfaatkan (Gusdi dkk., 2015). Keberadaan air tidak lepas dari siklus hidrologi, dengan adanya siklus tersebut maka air akan bersentuhan dengan senyawa sehingga air terkontaminasi dengan bahan lain. Jadi tidak ada air yang benarbenar murni. Pertumbuhan penduduk yang begitu pesat telah meningkatkan aktivitas manusia untuk memenuhi kebutuhan di segala sektor. Peningkatan ini mengakibatkan peningkatan intensitas pencemaran terhadap sumber daya air yang tersedia. Ditambah lagi perkembangan teknologi, yang tidak dipungkiri lagi dapat mencemari lingkungan, sehingga semakin menambah rusak sumber daya air permukaan yang tersedia (Rifa'i, 2007).

Teknik pengolahan air bersih dibagi menjadi tiga metode yaitu pengolahan secara fisika, kimia dan biologi. Salah satu proses dalam pengolahan air secara kimia adalah koagulasi. Koagulasi merupakan proses destabilisasi koloid dalam air dengan menambahkan bahan kimia (koagulan). Koagulan ditambahkan untuk menetralkan keadaan atau mengurangi partikel kecil yang tercampur dalam air melalui pengendapan. Koagulan yang biasa digunakan merupakan koagulan kimia, antara lain aluminium sulfat atau tawas, polyaluminium klorida, ferri klorida, ferri sulfat dan polymer kation (Wardani dkk., 2014).

Flokulasi merupakan kelanjutan dari proses koagulasi, dimana mikroflok hasil koagulasi mulai menggumpalkan partikel-partikel koloid menjadi flok-flok besar yang dapat diendapkan dan proses ini dibantu dengan pengadukan lambat. Proses koagulasi-flokulasi tidak dapat dipisahkan dalam pengolahan air karena kedua proses ini selalu dilakukan bersama. Mekanisme pembentukan flok-flok dalam proses koagulasi-flokulasi terdiri dari tiga tahap, yaitu tahap destabilisasi partikel-partikel koloid, tahap

${ }^{*}$ Correspondence:

Baby Melyta Pallar

e-mail: bsabymelyta@gmail.com

(c) 2020 the Author(s) retain the copyright of this article. This article is published under the terms of the Creative Commons Attribution License 4.0, which permits unrestricted non-commercial use, distribution, and reproduction in any medium, provided the original work is properly cited. 
pembentukan mikrofilik dan tahap pembentukan makrofilik. Tahap pertama dan kedua berlangsung selama proses koagulasi, sedangkan tahap ketiga berlangsung selama proses flokulasi. Pembentukan makrofilik dalam proses flokulasi terjadi karena tumbukan-tumbukan antara partikel koloid (Bangun dkk., 2013).

Proses flokulasi dilakukan setelah proses koagulasi dimana pada proses koagulasi kekokohan partikel koloid ditiadakan sehingga terbentuk flok-flok lembut yang kemudian dapat disatukan melalui proses flokulasi. Penggoyahan partikel koloid terjadi apabila elektrolit yang ditambahkan dapat diserap oleh partikel koloid sehingga muatan partikel menjadi netral. Penetralan muatan partikel oleh koagulan hanya mungkin terjadi jika muatan partikel mempunyai konsentrasi yang cukup kuat untuk mengadakan gaya tarik menarik antar partikel koloid. Proses flokulasi berlangsung dengan pengadukan lambat agar campuran dapat membentuk flok-flok yang berukuran lebih besar dan dapat mengendap dengan cepat. Keefektifan proses ini tergantung pada konsentrasi serta jenis koagulan dan flokulan, pH dan temperatur (Fuadi dkk., 2013).

Penggunaan bahan kimia yang digunakan sebagai koagulan dan flokulan mempunyai efek samping terhadap kesehatan. Beberapa studi melaporkan bahwa aluminium, senyawa alum, dapat memicu penyakit alzheimer, dilaporkan juga bahwa monomer beberapa polimer organik sintetik seperti PAC dan alum memiliki sifat neurotoksisitas (Hendrawati dkk., 2010).

Keberhasilan dalam proses pengolahan air minum berkaitan erat dengan penurunan kekeruhan dan kontaminan lainnya yang terkandung dalam air baku. Koagulan, terutama alum dan garam besi, umumnya digunakan untuk menghasilkan penurunan kekeruhan. Selain itu diinginkan pula koagulan yang dapat memberikan penurunan kekeruhan secara ekstensif dengan biaya rendah (Rachmawati dkk., 2009).

Selain penggunaan bahan kimia, beberapa tumbuhan dapat digunakan sebagai koagulan alami. Koagulan alami telah dilaporkan memiliki beberapa kelebihan lain dibandingkan dengan koagulan sintetis seperti tawas dan besi klorida, dalam hal itu, mereka menghasilkan jauh lebih rendah volume lumpur dan aman bagi manusia. Koagulan alami yang biodegradable dan biaya yang efektif untuk mengembangkan negara karena mereka dapat lokal berkembang dan memiliki rentang dosis efektif yang lebih luas untuk flokulasi berbagai suspensi koloid (Jadhav \& Mahajan, 2013). Tumbuhan yang dapat digunakan sebagai koagulan alami diantaranya serbuk biji kelor (Yuliastri, 2010), batang buah naga (Idris dkk., 2012), biji asam jawa dan biji kecipir (Hendrawati dkk., 2010), kaktus (Pichler dkk., 2012) dan lidah buaya (Mujariah, dkk., 2015).

Gel lidah buaya adalah salah satu tumbuhan yang dapat di gunakan sebagai koagulan alami seperti yang dilakukan Mujariah, dkk. (2015). Kandungan dalam lidah buaya memiliki kemiripan dengan kaktus yaitu terdapatnya kandungan mucilago atau gel yang terbukti dapat digunakan untuk menjernihkan air (Pichler dkk., 2012). Penggunaan bahan alami dilakukan sebisa mungkin untuk mengurangi penggunaan bahan sintetik yang menghasilkan efek samping dalam penggunaannya. Selain itu, koagulan bahan alami ini lebih murah dan lebih mudah ditemukan dalam kehidupan sehari-hari jika dibandingkan dengan koagulan sintetik yang digunakan dalam proses pemurnian air.

Tulisan ini dimaksudkan untuk mendeskripsikan tentang analisa koagulasi air sadah pada sumber air PDAM Kawatuna dengan menggunakan tanaman lidah buaya.

\section{Metode}

Alat yang digunakan dalam penelitian ini adalah micro pipet, gelas ukur, gelas erlenmeyer, gelas erlenmeyer, gelas kimia, botol semprot, $\mathrm{pH}$ meter, Colorimeter LaMotte, batang pengaduk, termometer, magnetic stirrer, mesin penghancur, buret, kain, pisau, wadah, spatula, dan pipet tetes. Sedangkan bahan yang digunakan dalam penelitian ini adalah sampel air dari PDAM Kawatuna, lidah Buaya (Aloe vera), $\mathrm{HNO}_{3}$, aquades, kertas saring dan tissue.

Sampel yang digunakan dalam penelitian ini adalah sumber air PDAM Kawatuna sedangkan sampel lidah buaya diambil dari pekarangan rumah warga di kota Palu.

\section{Preparasi Sampel}

Sampel air yang di pakai dalam penelitian ini berasal dari sumber air PDAM di Kawatuna, yang bersumber dari sungai Kawatuna (air permukaan). Sampel air diambil dengan menggunakan botol air mineral ukuran $1500 \mathrm{~mL}$ yang bagian luarnya telah dilapisi atau ditutup dengan lakban berwarna hitam kemudian dicelupkan ke dalam air hingga terisi penuh, selanjutnya ditambahkan larutan $\mathrm{HNO}_{3}$ ke dalamnya sebanyak $1 \mathrm{~mL}$. Sampel dibawa ke laboratorium untuk pengukuran dan analisis selanjutnya. Sebelum dilakukan pengerjaan sampel lebih lanjut dilakukan pengukuran kekeruhan, kesadahan, $\mathrm{pH}$, suhu dan warna terlebih dahulu (Lawanga, 2005).

Lidah buaya yang digunakan adalah lidah buaya tua yang telah diambil dan disimpan pada suhu ruang 2-3 hari. Daun lidah buaya dicuci dengan air untuk menghilangkan kotoran-kotoran yang menempel. Bagian luar atau kulit lidah buaya dikupas kemudian dipotong bagian dalamnya menjadi beberapa bagian yang lebih kecil. Daging dalam lidah buaya tersebut dihaluskan dengan menggunakan mesin penghancur hingga menjadi bubur. Lidah buaya yang telah menjadi bubur disaring sehingga diperoleh gel lidah buaya. Kemudian gel lidah buaya yang diperoleh tersebut disimpan dalam 
wadah yang bersih dan kering (Mujariah, dkk., 2015).

Sampel air sumur dimasukkan ke dalam erlenmeyer sebanyak $500 \mathrm{~mL}$, kemudian gel lidah buaya ditambahkan ke dalam air sebanyak 0,3 $\mathrm{mL}$. Selanjutnya diaduk menggunakan magnetic stirrer dengan kecepatan $120 \mathrm{rpm}$ selama 1 menit kemudian kecepatan dikurangi menjadi $30 \mathrm{rpm}$ selama 20 menit. Campuran didiamkan selama \pm 30 menit. Perlakuan 1-4 diulang untuk variasi gel lidah buaya $0,5 \mathrm{~mL}$ dan $1 \mathrm{~mL}$. Setiap variasi lama pengadukan selanjutnya dilakukan pengukuran fisika dan kimianya (Idris dkk., 2012).

\section{Pengujian Fisika dan Kimia}

\section{Pengujian Fisika}

\section{Penentuan Kekeruhan}

Sampel air yang akan dianalisa dimasukkan ke dalam tempat sampel dan selanjutnya dimasukkan ke dalam alat kalorimeter yang sebelumnya telah dikalibrasi dengan aquades. Mengatur jenis analisa yang akan dilakukan kemudian membaca nilai kekeruhan yang ditampilkan.

\section{Penentuan Suhu}

Sampel air diukur dengan menggunakan thermometer. Membiarkan selama satu sampai dua menit hingga keadaannya konstan. Selanjutnya mencatat skala derajat $\left({ }^{\circ} \mathrm{C}\right)$ yang terlihat pada thermometer. Selanjutnya mengukur suhu ruang dan mencatat skala derajatnya.

\section{Penentuan Warna}

Sampel air yang akan dianalisa dimasukkan ke dalam tempat sampel dan selanjutnya dimasukkan ke dalam alat colorimeter yang sebelumnya telah dikalibrasi dengan aquades. Mengatur jenis analisa yang akan dilakukan kemudian membaca nilai warna yang ditampilkan.

\section{Pengujian Kimia}

\section{Penentuan Kesadahan}

Sampel air yang akan dianalisa dimasukkan ke dalam tempat sampel yang mana sebelumnya ditambahkan dengan satu butir Calcium Hard Ind. sampai larut selanjutnya dimasukkan kedalam alat kalorimeter yang telah dikalibrasi dengan aquades. Mengatur jenis analisa yang akan dilakukan kemudian membaca nilai kesadahan yang ditampilkan.

\section{Penentuan pH}

Masing-masing sampel air yang diperoleh dari hasil penyaringan diukur $\mathrm{pH}$-nya dengan menggunakan $\mathrm{pH}$ meter yang sebelumnya telah dikalibrasi dengan menggunakan aquades (Lawanga, 2005).

\section{Penentuan Total Dissolved Solid (TDS)}

Sampel air yang akan dianalisa dimasukkan ke dalam tempat sampel dan selanjutnya dimasukkan ke dalam alat TDS meter yang sebelumnya telah dikalibrasi dengan aquades. Mengatur jenis analisa yanga akan dilakukan kemudian membaca nilai kekeruhan yang ditampilkan.

Prinsip kerja TDS meter adalah mengukur berapa jumlah padatan yang terlarut di dalam air dalam satuan $\mathrm{ppm}(\mathrm{mg} / \mathrm{L})$ yang ditunjukkan berupa angka pada displaynya (Manurung dkk., 2017).

\section{Hasil dan Pembahasan}

Sampel air yang digunakan pada penelitian ini yaitu sampel air PDAM yang bersumber dari sungai Kawatuna. Sampel air disimpan dalam wadah botol plastik bekas air mineral yang bagian luarnya telah dilapisi lakban berwarna hitam. Penelitian ini dilakukan berdasarkan 6 parameter yang diteliti diantaranya kesadahan, kekeruhan, warna, suhu, $\mathrm{pH}$ dan total dissolved solid (TDS). Sampel air diberi penambahan koagulan dengan jumlah yang bervariasi yaitu $0.3 \mathrm{~mL}, 0.5 \mathrm{~mL}$ dan $1 \mathrm{~mL}$ dalam $500 \mathrm{~mL}$ sampel air. Berikut ini hasil penelitian dari kelima parameter tersebut yang disajikan pada Tabel 1.

Table 1. Hasil analisis sampel sebelum dan sesudah pengolahan

\begin{tabular}{|c|c|c|c|c|c|c|c|}
\hline \multirow[b]{2}{*}{ No } & \multirow[b]{2}{*}{ Parameter } & \multirow[b]{2}{*}{ Satuan } & \multirow[b]{2}{*}{ Standar } & \multirow[b]{2}{*}{$\begin{array}{l}\text { Sebelum } \\
\text { Perlakuan }\end{array}$} & \multicolumn{3}{|c|}{ Setelah Perlakuan } \\
\hline & & & & & $\begin{array}{l}0.3 \\
\mathrm{~mL}\end{array}$ & $\begin{array}{l}0.5 \\
\mathrm{~mL}\end{array}$ & $1 \mathrm{~mL}$ \\
\hline 1 & Kesadahan & $\mathrm{mg} / \mathrm{L}$ & 500 & 233 & 212 & 204 & 197 \\
\hline 2 & Kekeruhan & NTU & 5 & 12 & 6 & 6 & 5 \\
\hline 3 & Warna & TCU & 15 & 137 & 72 & 72 & 68 \\
\hline 4 & Suhu & ${ }^{\circ} \mathrm{C}$ & $\begin{array}{c}\text { Suhu udara } \pm \\
3^{\circ} \mathrm{C}\end{array}$ & $31{ }^{\circ} \mathrm{C}$ & $31{ }^{\circ} \mathrm{C}$ & $30^{\circ} \mathrm{C}$ & $30^{\circ} \mathrm{C}$ \\
\hline 5 & $\mathrm{pH}$ & & $6.5-8.5$ & 2.97 & 3.21 & 3.61 & 4.18 \\
\hline 6 & TDS & $\mathrm{mg} / \mathrm{L}$ & 500 & 1472 & 556 & 413 & 331 \\
\hline
\end{tabular}


Penggunaan lidah buaya sebagai koagulan alami sudah pernah dilakukan sebelumnya. Peneliti sebelumnya menggunakan lidah buaya karena kandungan yang terdapat dalam lidah buaya sama seperti kandungan yang terdapat dalam kaktus yaitu asam poligalakturonat yang telah terbukti dapat menurunkan kekeruhan dalam air (Mujariah, dkk., 2015).

Unsur-unsur kimia yang terkandung di dalam daging lidah buaya menurut penelitian antara lain: lignin, saponin, anthaquinone, vitamin, mineral, gula, enzim, monosakarida, polisakarida, asam-asam amino essensial dan non essensial (Indriyanto dkk., 2014).

\section{Kekeruhan}

Kekeruhan adalah efek optik yang terjadi jika sinar membentuk material tersuspensi di dalam air. Kekeruhan air dapat ditimbulkan oleh adanya bahan-bahan organik dan anorganik seperti lumpur dan buangan, dari permukaan tertentu yang menyebabkan air sungai menjadi keruh. Kekeruhan walaupun hanya sedikit dapat menyebabkan warna yang lebih tua dari warna sesungguhnya. Air yang mengandung kekeruhan tinggi akan mengalami kesulitan bila diproses untuk sumber air bersih (Quddus, 2014). Menurut Mukkaromah (2016), kekeruhan pada air menunjukkan adanya indikasi TDS dalam air yang tinggi. Semakin keruh perairan maka semakin tinggi nilai TDS dalam air.

Sampel air PDAM diukur kekeruhannya dengan menggunakan alat kalorimeter. Air PDAM sebelum pengolahan memiliki kekeruhan yaitu 12 NTU yang mana nilai tersebut jauh dari standar yang diperbolehkan oleh Permenkes. Setelah penambahan koagulan lidah buaya diperoleh nilai masing-masing dengan variasi gel $0.3 \mathrm{~mL}$ yaitu $6 \mathrm{NTU}, 0.5 \mathrm{~mL}$ yaitu $5 \mathrm{NTU}$ dan 1 $\mathrm{mL}$ yaitu $5 \mathrm{NTU}$.

Berdasarkan hasil yang diperoleh, terlihat kekeruhan mengalami penurunan yang cukup besar. Menurut peraturan menteri kesehatan RI No 491/2010 tentang persyaratan kualitas air minum yang diperbolehkan untuk batas maksimum kekeruhan air yaitu 5 NTU, sedangkan pada sampel air PDAM Kawatuna tersebut kekeruhannya sudah sesuai dengan batas maksimum yang diperbolehkan oleh Menteri Kesehatan. Penurunan nilai kekeruhan dapat dilihat dalam Gambar 1.

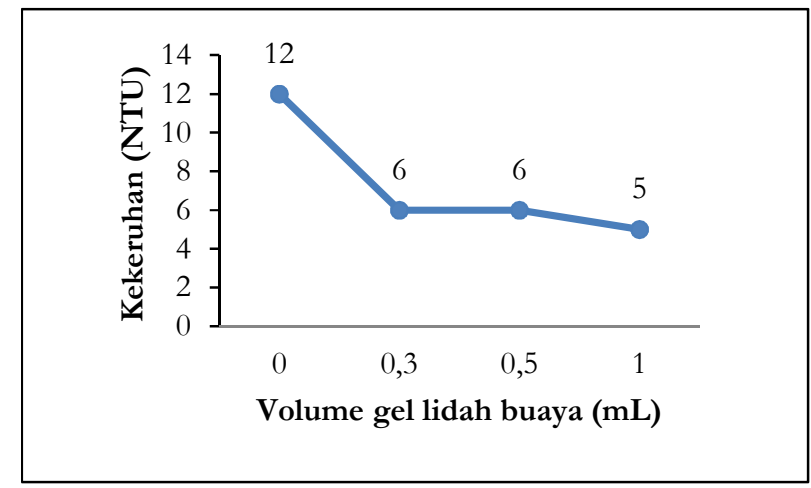

Gambar 1. Hubungan antara volume gel lidah buaya dengan kekeruhan air

Berdasarkan hasil yang diperoleh, terlihat bahwa dengan penambahan gel lidah buaya dapat mempengaruhi penurunanan kadar kekeruhan. Semakin banyak jumlah gel lidah buaya yang ditambahkan maka semakin menurun kadar kekeruhannya. Penambahan koagulan gel lidah buaya untuk $0.3 \mathrm{~mL}$ terjadi penurunan kekeruhan sebesar $50 \%$, untuk $0.5 \mathrm{~mL}$ terjadi penurunan yang sama yaitu $50 \%$ dan untuk $1 \mathrm{~mL}$ penurunan kekeruhan sebesar 58.33\%.

Banyak faktor yang mempengaruhi kekeruhan air, seperti pembuangan hasil aktifitas masyarakat. Selain itu, perbedaan musim antara kemarau dan penghujan juga dapat menyebabkan tingkat kekeruhan air yang berbeda (Ayundyahrini dkk., 2013).

\section{Kesadahan}

Kesadahan merupakan sifat air yang mengandung ion-ion logam valensi dua, dimana ion penyebab utama kesadahan yaitu $\mathrm{Ca}$ dan $\mathrm{Mg}$. Kesadahan berasal dari kontak terhadap tanah dan pembentukan batuan. Air yang mempunyai tingkat kesadahan yang tinggi menyebabkan timbulnya kerak pada peralatan masak, menimbulkan endapan berwarna putih, menyebabkan sabun kurang membusa sehingga meningkatkan konsumsi sabun, menimbulkan korosi pada peralatan yang terbuat dari besi (Ristiana dkk., 2009).

Kesadahan air PDAM Kawatuna sebelum pengolahan adalah $233 \mathrm{mg} / \mathrm{L}$. Nilai kesadahan tersebut telah memenuhi standar yang ditetapkan oleh PerMenKes No 492/2010 standar kesadahan air yaitu $500 \mathrm{mg} / \mathrm{L}$. Setelah penambahan koagulan lidah buaya terjadi penurunan kesadahan untuk variasi $0.3 \mathrm{~mL}$ yaitu 212 , untuk variasi $0.5 \mathrm{~mL}$ : 204 dan untuk variasi $1 \mathrm{~mL}$ : 197. Setelah dilakukan pengolahan terjadi penurunan 
kesadahan dimana pada penambahan koagulan gel lidah buaya untuk $0.3 \mathrm{~mL}$ terjadi penurunan kesadahan sebesar $9.01 \%$, untuk $0.5 \mathrm{~mL}$ terjadi penurunan sebesar $12.44 \%$ dan untuk $1 \mathrm{~mL}$ terjadi penurunan sebesar $15.45 \%$. Penurunan kesadahan dapat dilihat pada Gambar 2.
Berdasarkan hasil yang diperoleh, menunjukkan bahwa penambahan jumlah gel lidah buaya mempengaruhi penurunan kesadahan air. Semakin banyak jumlah gel lidah buaya yang ditambahkan maka semakin berkurang kesadahan airnya.

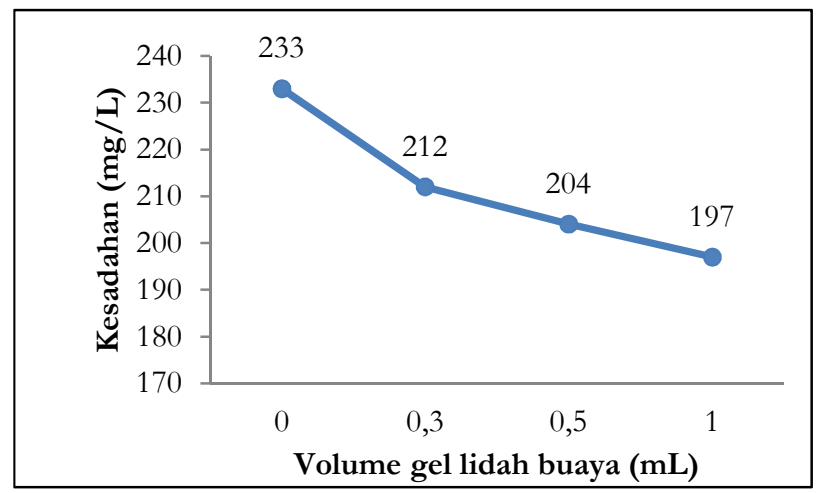

Gambar 2. Hubungan antara volume gel lidah buaya dengan kesadahan air

Kesadahan air merupakan sifat alami dari air itu sendiri. Kadar kesadahan air ini berbedabeda di masing-masing tempat tergantung pada kondisi tanah daerah tersebut. Kesadahan dalam air menunjukkan bahwa terjadi kontak antara formasi geologi dengan badan air tersebut. Sampai ambang batas maksimum yang dianjurkan yaitu $350 \mathrm{ppm}$, kesadahan air tidak menjadi masalah (Astuti, 2005).

\section{Warna}

Warna air PDAM Kawatuna diukur dengan menggunakan alat kalorimeter. Sebelum pengolahan, air PDAM memiliki warna yaitu 137 TCU. Setelah penambahn gel lidah buaya terjadi penurunan warna yaitu pada variasi $0.3 \mathrm{~mL}$ : 72
TCU, pada variasi $0.5 \mathrm{~mL}$ : 72 TCU dan pada variasi $1 \mathrm{~mL}$ : $68 \mathrm{TCU}$. Berdasarkan hasil yang diperoleh tersebut, diketahui bahwa terjadi penurunan warna yang cukup besar namun belum sesuai dengan Peraturan Menteri Kesehatan RI No 491/2010 tentang persyaratan kualitas air minum yang diperbolehkan untuk batas maksimum warna air yaitu $15 \mathrm{TCU}$.

Penambahan gel lidah buaya pada air PDAM terjadi penurunan warna dimana pada penambahan sebanyak $0.3 \mathrm{~mL}$ terjadi penurunan sebesar $47.44 \%$, nilai yang sama juga terjadi pada penambahan sebanyak $0.5 \mathrm{~mL}$ yaitu sebesar $47.44 \%$, dan pada penambahan $1 \mathrm{~mL}$ penurunan warnanya mencapai $50.36 \%$. Penurunan nilai kekeruhan dapat dilihat dalam Gambar 3.

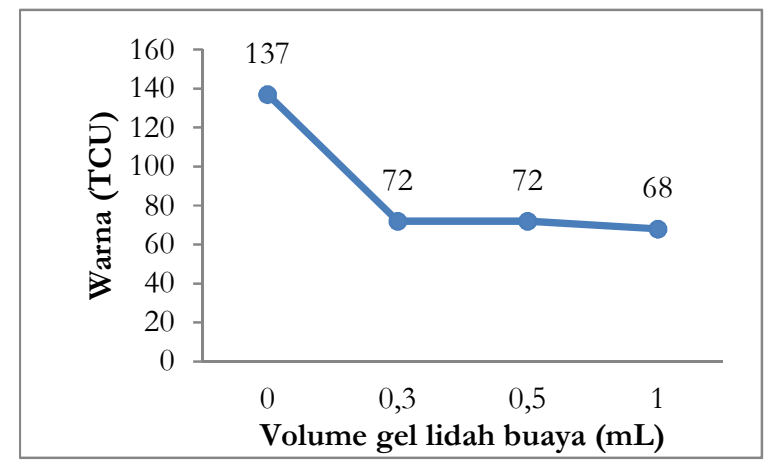

Gambar 3. Hubungan antara volume gel lidah buaya dengan warna air

Berdasarkan hasil yang diperoleh, terlihat bahwa gel lidah buauya mampu menurunkan kadar warna dalam sampel air. Semakin banyak jumlah lidah buaya yang digunakan maka semakin turun kadar warnanya. Walaupun hasil yang diperoleh belum memenuhi standar warna yang dianjurkan oleh Permenkes yaitu $15 \mathrm{TCU}$, namun dalam hal ini lidah buaya sudah mampu mengurangi kadar warna air hampir setengah dari nilai awal sebelum penambahan lidah buaya. 


\section{Suhu}

Salah satu faktor yang mempengaruhi proses koagulasi adalah temperatur sehingga pengaturan temperatur perlu diperhatikan untuk memperoleh hasil yang optimum (Hendrawati dkk., 2010). Menurut Mukkaromah (2016), suhu air dipengaruhi oleh berbagai faktor seperti intensitas cahaya matahari, pertukaran panas antara air dengan udara sekelilingnya, dan ketinggian geografis.

Suhu air PDAM sebelum penambahan lidah buaya yaitu $31^{\circ} \mathrm{C}$. Setelah penambahan lidah buaya pada variasi 0,3 belum terjadi penurunan yaitu tetap $31^{\circ} \mathrm{C}$, pada variasi $0.5 \mathrm{~mL}$ dan $1 \mathrm{~mL}$ terjadi penurunan yaitu $30^{\circ} \mathrm{C}$. Suhu yang sesuai berdasarkan Peraturan Menteri Kesehatan yaitu memiliki selisih suhu $\pm 3^{\circ} \mathrm{C}$. Penambahan gel lidah buaya pada air PDAM tidak memberi pengaruh yang signifikan pada saat sebelum dan sesudah penambahan dilakukan. Dalam hal ini suhu air masih dalam ambang batas yang normal, karena tidak berbeda jauh dari suhu udara.

\section{Derajat Keasamaan (pH)}

Derajat keasaman (pH) merupakan gambaran jumlah atau aktivitas ion hidrogen dalam perairan. Secara umum, nilai $\mathrm{pH}$ menggambarkan seberapa besar tingkat keasaman atau kebasaan suatu perairan. Perairan dengan nilai $\mathrm{pH}=7$ adalah netral, $\mathrm{pH}<7$ dikatakan kondisi perairan bersifat asam, sedangkan $\mathrm{pH}>7$ dikatakan kondisi perairan bersifat basa (Effendi, 2003). Proses koagulasi sangat dipengaruhi oleh $\mathrm{pH}$. Koagulan memiliki rentang $\mathrm{pH}$ tertentu untuk mencapai koagulasi yang optimum. Oleh karena itu, air yang akan diberi perlakuan harus memiliki $\mathrm{pH}$ yang memadai untuk dapat bereaksi dengan koagulan sehingga menghasilkan flok (Hendrawati dkk., 2010).

$\mathrm{pH}$ air diukur dengan menggunakan $\mathrm{pH}$ meter. Berdasarkan Permenkes $\mathrm{pH}$ air yang disarankan yaitu 6.5-8.5. pH air sebelum pengolahan adalah 2.97. Setelah penambahan lidah buaya terjadi penurunan $\mathrm{pH}$ yaitu pada variasi $0.3 \mathrm{~mL}: 3.21$, pada variasi $0.5 \mathrm{~mL}: 3.61$ dan pada variasi $1 \mathrm{~mL}: 4.18$. Perubahan nilai $\mathrm{pH}$ dapat dilihat pada Gambar 4.

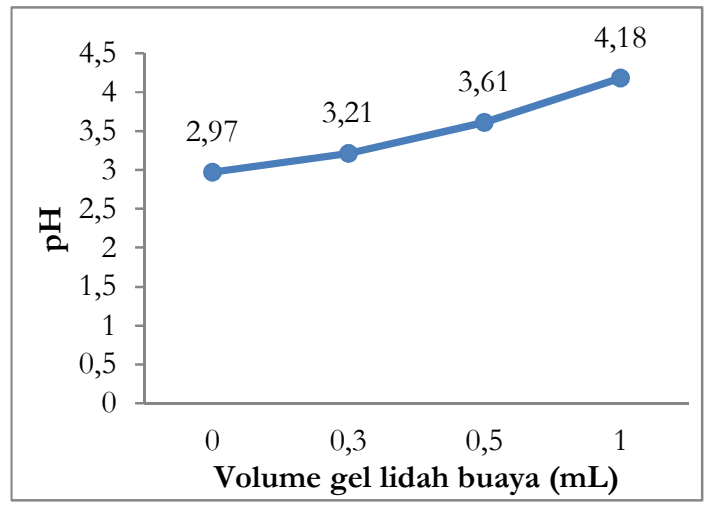

Gambar 4. Hubungan antara volume gel lidah buaya dengan $\mathrm{pH}$ air

Berdasarkan hasil yang diperoleh, nilai pH pada saat sebelum penambahan menunjukkan bahwa $\mathrm{pH}$ air sangat asam. Setelah penambahan gel lidah buaya terlihat bahwa terjadi perubahan nilai $\mathrm{pH}$ namun belum sesuai standar peraturan menteri kesehatan dimana ambang batasnya berkiaar antara 6.5-8.5 karena nilai $\mathrm{pH}$ masih menunjukkan bahwa air tersebut masih bersifat asam. Hal ini terjadi disebabkan karena $\mathrm{pH}$ lidah buaya yang juga bersifat asam yaitu sekitar 4-5.

\section{Total Dissolved Solid (TDS)}

Total dissolved solid (TDS) atau padatan terlarut adalah padatan-padatan yang mempunyai ukuran lebih kecil dari padatan tersuspensi. Bahan-bahan terlarut pada perairan alami tidak bersifat toksik, akan tetapi jika berlebihan dapat meningkatkan nilai kekeruhan yang selanjutnya akan menghambat penetrasi cahaya matahari dan mempengaruhi proses fotosintesis diperairan (Paramita dkk., 2012). Sebelum dilakukan penambahan lidah buaya, jumlah TDS awal air PDAM yaitu 1472. Hasil ini menunjukkan bahwa jumlah TDS pada air PDAM jauh dari standar yang diperbolehkan oleh Permenkes. Setalah penambahan koagulan lidah buaya, terjadi penurunan nilai TDS, dimana pada penambahan $0.3 \mathrm{~mL}: 556 \mathrm{mg} / \mathrm{L}, 0.5 \mathrm{~mL}: 413 \mathrm{mg} / \mathrm{L}$ dan pada penambahan $1 \mathrm{~mL}: 331 \mathrm{mg} / \mathrm{L}$. Berdasarkan hasil yang diperoleh setelah penambahan koagulan lidah buaya, menunjukkan bahwa nilai TDS pada air PDAM mengalami penurunan yang sangat drastis. Perubahan nilai TDS dapat dilihat pada Gambar 5. 


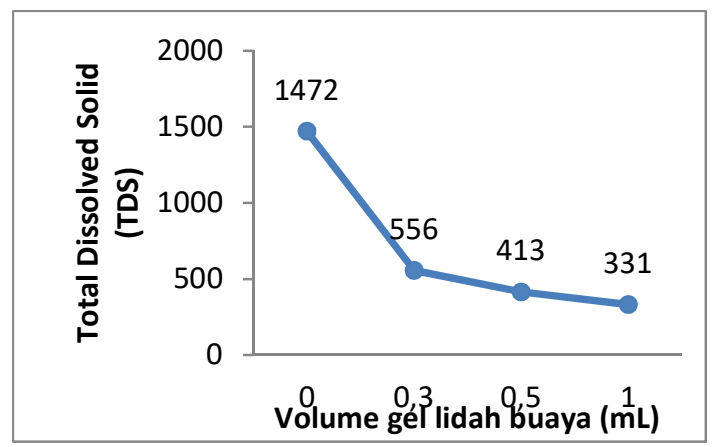

Gambar 5. Hubungan antara volume gel lidah buaya dengan TDS air

Berdasarkan hasil yang diperoleh, terlihat bahwa dengan penambahan gel lidah buaya dapat mempengaruhi penurunanan nilai TDS. Semakin banyak jumlah gel lidah buaya yang ditambahkan maka semakin menurun kadar TDSnya. Penambahan koagulan gel lidah buaya untuk 0.3 $\mathrm{mL}$ terjadi penurunan kekeruhan sebesar $62.22 \%$, untuk $0.5 \mathrm{~mL}$ terjadi penurunan sebesar $71.94 \%$ dan untuk $1 \mathrm{~mL}$ penurunan kekeruhan sebesar $77.51 \%$.

\section{Kesimpulan}

Gel lidah buaya dapat digunakan sebagai koagulan alami dalam menjernihkan air PDAM Kawatuna. Nilai kekeruhan air turun dari 12 NTU menjadi 5 NTU sedangkan kesadahan turun dari $233 \mathrm{mg} / \mathrm{L}$ menjadi $197 \mathrm{mg} / \mathrm{L}$. Untuk warna turun dari 137 TCU menjadi 68 TCU. Penambahan gel lidah buaya juga mengakibatkan perubahan pada nilai TDS, dimana nilai awal TDS sebelum penambahan yaitu 1472 setelah dilakukan penambahan lidah buaya menjadi 331 . Penambahan koagulan gel lidah buaya tidak mengakibatkan perubahan suhu air secara signifikan karena sebelum pengolahan yaitu $31^{\circ} \mathrm{C}$ dan sesudah penambahan yaitu $30^{\circ} \mathrm{C}$. Sedangkan penambahan gel lidah buaya mengakibatkan perubahan $\mathrm{pH}$ yang semakin mendekati nilai yang dianjurkan. pH awal air yaitu 2.97 menjadi 4.18.

\section{Ucapan Terima Kasih}

Penulis mengucapkan terimakasih kepada laboran Laboratorium Kimia FKIP Universitas Tadulako dan semua pihak yang banyak membantu penulis dalam menyelesaikan penelitian ini.

\section{Referensi}

Alwi, M., \& Maulina, S. (2012). Pengujian bakteri coliform dan escherichia coli pada beberapa depot air minum isi ulang di Kecamatan Palu Timur Kota Palu. Jurnal Biocelebes, 6(1), 4047.

Astuti, W. (2005). Proses pelunakan air sadah menggunakan zeolit alam lampung. Widya Riset, 8(1), 1-7.
Ayundyahrini, M., Effendie, A. K. R., \& Gamayanti, N. (2013). Estimasi dosis aluminium sulfat pada proses penjernihan air menggunakan metode genetic algorithm. Jurnal Teknik Pomits, 1(1), 1-6.

Bangun, A. R., Aminah, S., Hutahaean, R. A., \& Ritonga, M. Y. (2013). Pengaruh kadar air, dosis dan lama pengendapan koagulan serbuk biji kelor sebagai alternatif pengolahan limbah cair industri tahu. Jurnal Teknik Kimia Universitas Sumatera Utara, 2(1), 7-13.

Effendi, H. (2003). Telaah kualitas air bagi sumber daya dan lingkungan perairan. Yogyakarta: Kanisius.

Fuadi, A., Munawar, \& Mulyani. (2013). Penentuan karakteristik air waduk dengan metode koagulasi. Jurnal Sains dan Teknologi Reaksi, 11(1), 7-14.

Gusdi, R., Wita, H., \& Septiana, U. (2015). Pembuatan alat penyaringan air sederhana dengan metode fisika. Jurnal Nasional Ecopedon, 4(1), 19-21.

Hendrawati, Syamsumarsih, D., \& Nurhasni. (2010). Penggunaan biji asam jawa (tamarinus indica 1.) dan biji kecipir (psophocarpus tetragonolobus l.) sebagai koagulan alami dalam perbaikan kualitas air tanah. Jurnal Kimia Valensi, 3(1), 22-33.

Idris, J., Som, A. M., Musa, M., Hamid, K. H. K., Husen, R., \& Rodhi, M. N. M. (2012). Dragon fruit foliage plant-based coagulant for treatment of concentrated latex effluent: comparison of treatment with ferric sulfate. Journal of Chemistry, 2013(38), 1-7.

Indriyanto, I., Wahyuni, S., \& Pratjojo, W. (2014). Pengaruh penambahan kitosan terhadap karakteristik plastik biodegradable pektin lidah buaya. Indonesian Journal Chemical of Science, 3(2), 1-6.

Jadhav, M. V., \& Mahajan, Y. S. (2013). A comparative study of natural coagulants in flocculation of local clay suspensions of varied turbidities. Journal of Civil Engineering and Technology, 17(2), 26 -39. 
Lawanga, A. F. (2005). Penyaringan limbah cair industri secara koagulasi. Skripsi Tidak Diterbitkan. Palu: Universitas Tadulako.

Manurung, M., Ivansyah, O., \& Nurhasanah. (2017). Analisis kualitas air sumur bor di Pontianak setelah proses penjernihan dengan metode aerasi, sedimentasi dan filtrasi. Prisma Fisika, 5(1), 45-50.

Mujariah, Abram, P. H., \& Jura, M. R. (2015). Pengunaan gel lidah buaya (aloe vera) sebagai koagulan alami dalam penjernihan air sumur di desa Sausu Tambu Kecamatan Sausu. Jurnal Akademika Kimia, 5(1), 16-21.

Mukkaromah, R. (2016). Analisis sifat fisis dalam studi kualitas air di mata air sumber asem dusun Kalijeruk, Desa Siwuran, Kecamatan Garung, Kabupaten Wonosobo. Skripsi Tidak Diterbitkan. Semarang: Universitas Negeri Semarang.

Paramita, P., Shovitri, M., \& Kuswytasari, N. D. (2012). Biodegradasi limbah organik pasar dengan menggunakan mikroorganisme alami tangki septik. Jurnal Sains dan Seni, 1(1), 2326.

Peraturan Menteri Kesehatan RI. No. 492/MenKes/Per/IV/Tahun 2010. Persyaratan kualitas air minum. Jakarta: Permenkes.

Pichler, T., Young, K., \& Alcantar, N. (2012). Eliminating turbidity in drinking water using the mucilage of a common cactus. Water Science \& Technology: Water Supply, 12(2), 179-186.
Quddus, R. (2014). Teknik pengolahan air bersih dengan sistem saringan pasir lambat (downflow) yang bersumber dari sungai Musi. Jurnal Teknik Sipil dan Lingkungan, 2(4), 669-675.

Rachmawati S. W., Iswanto, B., \& Winarni. (2009). Pengaruh $\mathrm{pH}$ pada proses koagulasi dengan koagulan aluminum sulfat dan ferri klorida. Jurnal Teknologi Lingkungan, 5(2), 40-45.

Rifa'i, J. (2007). Pemeriksaan kualitas air bersih dengan koagulan alum dan pac di ipa jurug PDAM kota Surakarta. Skripsi Tidak Diterbitkan. Surakarta: Universitas Sebelas Maret.

Ristiana, N., Astuti, D., \& Kurniawan, T. P. (2009). Kefektifitan ketebalan kombinasi zeolit dengan arang aktif dalam menurunkan kadar kesadahan air sumur di Karangtengah Weru Kabupaten Sukaharjo. Jurnal Kesehatan, 2(1), 91-102.

Wardani, F. A., \& Agung, R. T. (2014). Pemanfaatan biji asam jawa (tamarindus indica) sebagai koagulan alternatif dalam proses pengolahan air sungai. Jurnal Ilmiah Teknik Lingkungan, 7(2), 85-91.

Yuliastri, I. R. (2010). Penggunaan serbuk biji kelor (moringa oleifera) sebagai koagulan dan flokulan dalam perbaikan kualitas air limbah dan air tanah. Skripsi Tidak Diterbitkan. Jakarta: Universitas Islam Negeri Syarif Hidayatullah. 